\title{
Latitudinal distribution of reactive iodine in the Eastern Pacific and its link to open ocean sources
}

\author{
A. S. Mahajan ${ }^{1, *}$, J. C. Gómez Martín ${ }^{1,4}$, T. D. Hay ${ }^{1}$, S.-J. Royer ${ }^{2}$, S. Yvon-Lewis ${ }^{3}$, Y. Liu ${ }^{3}$, L. Hu ${ }^{3}$, \\ C. Prados-Roman ${ }^{1}$, C. Ordóñez ${ }^{1, * *}$, J. M. C. Plane ${ }^{4}$, and A. Saiz-Lopez ${ }^{1}$ \\ ${ }^{1}$ Laboratory for Atmospheric and Climate Science (CIAC), CSIC, Toledo, Spain \\ ${ }^{2}$ Institut de Ciències del Mar (CSIC), Barcelona, Spain \\ ${ }^{3}$ Oceanography Department, Texas A\&M University, College Station, Texas, USA \\ ${ }^{4}$ School of Chemistry, University of Leeds, Leeds, UK \\ *now at: Indian Institute of Tropical Meteorology (IITM), Pune, India \\ ** now at: British Met Office, Exeter, UK
}

Correspondence to: A. Saiz-Lopez (a.saiz-lopez@ciac.jccm-csic.es)

Received: 11 May 2012 - Published in Atmos. Chem. Phys. Discuss.: 18 June 2012

Revised: 22 November 2012 - Accepted: 23 November 2012 - Published: 5 December 2012

\begin{abstract}
Ship-based Multi-Axis Differential Optical Absorption Spectroscopy measurements of iodine monoxide (IO) and atmospheric and seawater Gas ChromatographyMass Spectrometer observations of methyl iodide $\left(\mathrm{CH}_{3} \mathrm{I}\right)$ were made in the Eastern Pacific marine boundary layer during April 2010 as a part of the HaloCarbon Air Sea TransectPacific (HaloCAST-P) scientific cruise. The presence of IO in the open ocean environment was confirmed, with a maximum differential slant column density of $5 \times 10^{13}$ molecules $\mathrm{cm}^{-2}$ along the $1^{\circ}$ elevation angle (corresponding to approximately $1 \mathrm{pptv}$ ) measured in the oligotrophic region of the Southeastern Pacific. Such low IO mixing ratios and their observed geographical distribution are inconsistent with satellite estimates and with previous understanding of oceanic sources of iodine. A strong correlation was observed between reactive iodine (defined as $\mathrm{IO}+\mathrm{I}$ ) and $\mathrm{CH}_{3} \mathrm{I}$, suggesting common sources. In situ measurements of meteorological parameters and physical ocean variables, along with satellite-based observations of Chlorophyll $a(\mathrm{Chl} a$ ) and Chromophoric Dissolved Organic Matter (CDOM) were used to gain insight into the possible sources of iodine in this remote environment. Surprisingly, reactive iodine showed a negative correlation (>99\% confidence) to Chl $a$ and CDOM across the cruise transect. However, a significant positive correlation (>99\% confidence) with sea surface temperature (SST) and salinity instead suggests a widespread abiotic source related to the availability of aqueous iodine and to temperature.
\end{abstract}

\section{Introduction}

The recent observation of significant slant column densities (SCDs) of iodine monoxide (IO) over a large region of the Eastern Pacific from the satellite-borne instrument SCIAMACHY (Schönhardt et al., 2008) has raised the question of the potential climatic impact of iodine chemistry on a regional-global scale, given its well known link with ozone $\left(\mathrm{O}_{3}\right)$ depletion, changes to the oxidizing capacity of the marine boundary layer (MBL) by affecting $\mathrm{HO}_{\mathrm{x}}$ and $\mathrm{NO}_{\mathrm{x}}$, and new particle formation (see Saiz-Lopez et al., 2012b and references therein). However, validation of satellite measurements in remote oceanic regions and research on iodine emission mechanisms and their dependence on climatically sensitive variables are required before including this chemistry in standard global chemistry-climate models.

Measurements of reactive iodine species $(\mathrm{RIS}=\mathrm{I}, \mathrm{IO}$, $\mathrm{OIO})$ in the open ocean MBL are rare, with only a few reported observations (Allan et al., 2000; Mahajan et al., 2010a; Read et al., 2008; Oetjen, 2009; Saiz-Lopez et al., 2011) mostly in regions where the satellite observations are under detection limit (typically $3 \times 10^{12}$ molecules $\mathrm{cm}^{-2}$ for monthly averages, Schönhardt et al., 2008). Hence, the geographical distribution of RIS over the majority of the world's oceans is not well known. In the Eastern Pacific, satellite observations indicate slant columns of up to $6 \times 10^{12}$ molecules $\mathrm{cm}^{-2}$, although the signal-to-noise ratio

Published by Copernicus Publications on behalf of the European Geosciences Union. 
in the lower latitudes is poor (Schönhardt et al., 2008). Observation of such enhanced IO slant columns above the biologically active region off the coast of Peru would be consistent with the source of IO being the production of iodinecontaining species by marine algae due to the high Chlorophyll $a(\mathrm{Chl} a)$ content in upwelling regions. However, these observations have not been validated using ground-based instruments.

The above mentioned field studies in the open ocean have found no clear correlation between iodinated compounds and other biotic or abiotic parameters displaying near constant mixing ratios of IO during the daytime (Read et al., 2008). Known biological sources of IO precursors, iodocarbons (Carpenter et al., 1999) and $\mathrm{I}_{2}$ (Saiz-Lopez and Plane, 2004), include macroalgae like Laminaria digitata, particularly in coastal environments, and open ocean pico-nanophytoplankton such as Prochlorococcus spp. - a ubiquitous marine cyanobacterium - and Phaeocystis globosa (SmytheWright et al., 2006, 2010). However, a more recent study by Brownell et al. (2010) suggested much lower emission rates from these phytoplankton (Brownell et al., 2010). Other studies have proposed different production mechanisms over the ocean surface: (i) a photochemical mechanism based on the recombination of $\mathrm{CH}_{3}$ radicals with I atoms, where the $\mathrm{CH}_{3}$ radicals are formed from the photolysis of humic materials and the I atoms are formed from the oxidation of iodide $\left(\mathrm{I}^{-}\right)$ (Moore and Zafiriou, 1994); (ii) a chemical mechanism based on the oxidation of $\mathrm{I}^{-}$by $\mathrm{O}_{3}$ taken up on the surface and the subsequent reaction of $\mathrm{HOI}$ and $\mathrm{I}_{2}$ with dissolved organic matter (DOM) or direct emission (Garland and Curtis, 1981; Martino et al., 2009), (iii) oxidation of halogen anions by Chl $a$ or aromatic ketones, which leads to formation of organic halogens in the presence of organic compounds (Jammoul et al., 2009; Reeser et al., 2009) and (iv) a substitution mechanism based on the input of mineral dust providing a suitable oxidant like Fe(III) (Williams et al., 2007). However, none of the above mechanisms are shown to be dominant in the open ocean environment, and field data to support the laboratory experiments are not available.

In an effort to improve our understanding of the role of RIS in the open ocean MBL and the sources of their precursors, a field study was conducted in the Eastern Pacific in April 2010 as part of the HaloCarbon Air Sea Transect-Pacific (HaloCAST-P) experiment on board of the R/V Thomas Thompson. The HaloCAST-P cruise departed from Punta Arenas, Chile on 27 March 2010 and arrived at Seattle, USA on 26 April 2010. The track comprised a short fourday run up the inland passage from Punta Arenas to Puerto Montt, followed by a long transect through the Eastern Pacific Ocean during which air masses of different origin were sampled (Fig. 1). Here, we report IO data collected during the cruise with the Multi-AXis Differential Optical Absorption Spectroscopy (MAX-DOAS) technique, in addition to gas chromatography-mass spectrometry (GC-MS) measurements of $\mathrm{CH}_{3} \mathrm{I}$ in air and seawater, and use these results to:

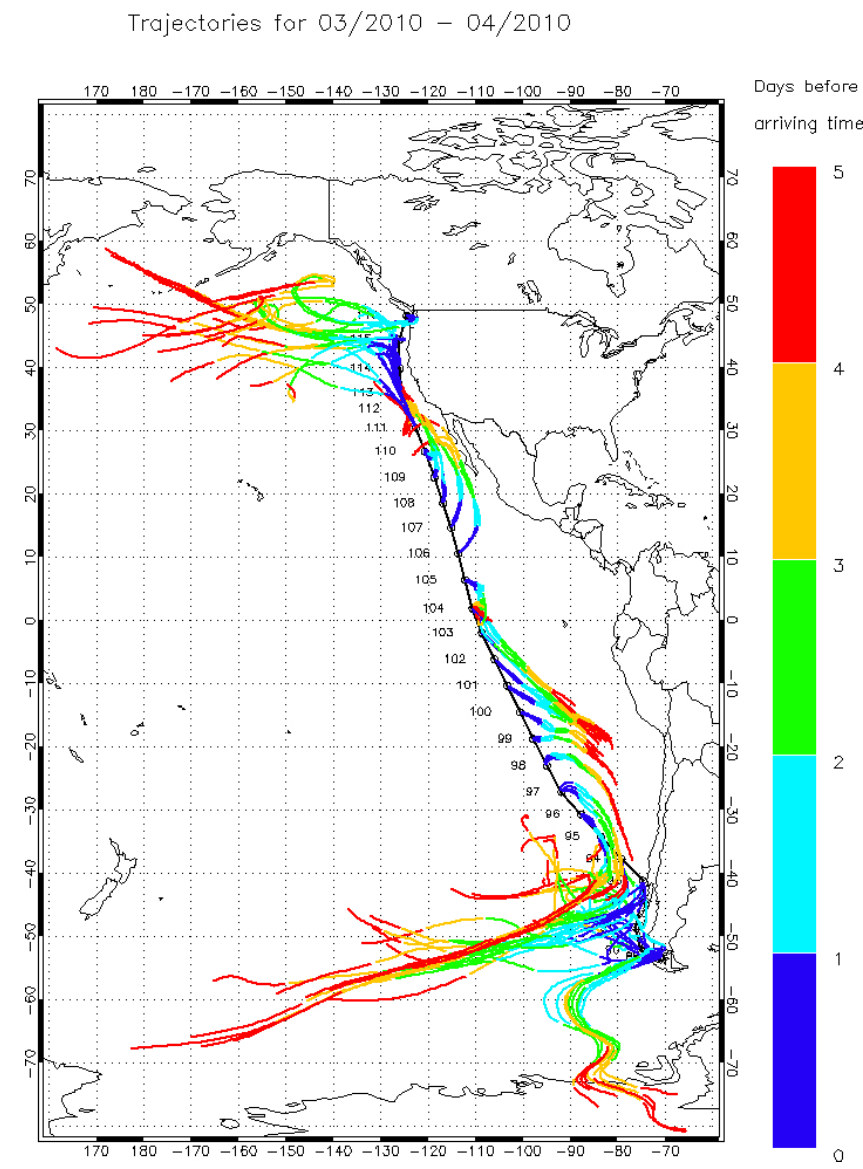

Fig. 1. The cruise track along with the 5-day back trajectories, calculated using HYbrid Single-Particle Lagrangian Integrated Trajectory (HYSPLIT), arriving during noon on every day of the cruise (Draxler and Rolph, 2003).

(i) assess the geographical distribution of RIS in the Eastern Pacific along a latitudinal transect and provide information for validation of IO satellite retrievals; and (ii) discuss emission mechanisms of precursors of RIS by studying correlations with potentially related oceanic variables such as sea surface temperature (SST), Chl $a$, salinity, Chromophoric DOM (CDOM) and other meteorological data.

\section{Measurement techniques}

A MAX-DOAS instrument was set up on the second deck of the research vessel. The instrument makes use of scattered sunlight along different elevation angles and by combination of several lines of sight including the zenith, the concentration of an absorber in the boundary layer can be obtained either, in a first approximation by a simple geometric approach or alternatively, by simulating the light path with a radiative transfer model taking into account also multiple scattering effects and the correct treatment of the aerosol loading in the atmosphere (Hönninger et al., 2004; 
Platt and Stutz, 2008; Wagner et al., 2004). This instrument has been successfully used in the past to retrieve halogen oxides in other environments (Mahajan et al., 2010b). The outdoor unit, containing a scanning telescope, was mounted on a gimbal table in order to compensate for the pitch and roll of the ship. This setup dampened the effective oscillations to within $\pm 2^{\circ}$ for most of the cruise. Additionally, a high sensitivity $\left( \pm 0.01^{\circ}\right)$ fast response $(0.1 \mathrm{~s})$ inclinometer (SST100-B+L IM) was used to log the residual oscillations, which were then corrected for during the analysis procedure. The true elevation angle is given by the sum of the prearranged elevation angle and the inclinometer angle. Only true elevation angles within a variation of $0.2^{\circ}$ were used for analysis. The telescope was pointing towards the front of the ship with a clear line of view towards the forward horizon to avoid interference from exhaust emissions. The scanning system consists of a telescope focusing the collected light on a 19 optic fiber bundle mounted on a stepper motor, which allows the collection of scattered sunlight from discrete elevation angles $\left(1^{\circ}, 3^{\circ}, 5^{\circ}, 7^{\circ}, 9^{\circ}, 15^{\circ}, 30^{\circ}\right.$, and $90^{\circ}$ ). A $7.5 \mathrm{~cm}$ focal length, $2.5 \mathrm{~cm}$ diameter quartz lens was used, constraining the field of view to $\sim 1^{\circ}$. The indoor unit, comprising a spectrometer (Princeton Instruments SP500i), a CCD camera (Princeton Instruments Pixis 400B) and a computer to log data, was placed in a temperature-stabilized laboratory. A 1200 grooves $\mathrm{mm}^{-1}$ grating was used resulting in a $40 \mathrm{~nm}$ spectral window and a spectral resolution of $0.25 \mathrm{~nm}$ FWHM. Spectra were recorded with a short exposure time $(1 \mathrm{~s})$ per angle to reduce the contribution from varying elevation angles due to oscillations from the ship motion, which had a typical frequency of 10-20 s. A complete cycle of elevation angles took $\sim 30 \mathrm{~s}$ to measure and the instrument focused on each wavelength window specified (see below) for one hour. There was no appreciable wavelength shift $(<0.1 \mathrm{~nm})$ noticed in the spectra and the spectra were recalibrated before analysis using the Fraunhoffer absorption lines. The data were then averaged for $30 \mathrm{~min}$ to improve the signal to noise ratio. For DOAS retrieval of IO using the QDOAS software (Fayt and Van Roozendael, 2011), cross-sections of IO (Gómez Martín et al., 2005), $\mathrm{NO}_{2}$ (Vandaele et al., 1997), $\mathrm{H}_{2} \mathrm{O}$ (Rothman et al., 2003), $\mathrm{O}_{4}$ (Hermans, 2002), $\mathrm{O}_{3}$ (Burrows et al., 1999) and Ring (following Chance and Spurr, 1997) were fitted to the spectra together with a 2 nd order polynomial. The instrument alternated between two different spectral windows to allow the retrieval of $\mathrm{BrO}(318-358 \mathrm{~nm})$ and IO (416-456 nm) spectral features. For IO, the spectral deconvolution was performed in the 416$439 \mathrm{~nm}$ wavelength window, and the zenith spectrum from each scan was used as a reference to minimize the influence of instrumental instabilities and largely eliminate absorptions of trace gases in the stratosphere. Typically, the residual RMS was in the $1.5 \times 10^{-4}$ to $5 \times 10^{-4}$ range, resulting in $2 \sigma$ IO differential slant column densities (DSCD) detection limits of $1 \times 10^{13}$ to $3 \times 10^{13}$ molecules $\mathrm{cm}^{-2}$. An example of the fit is shown in Fig. 2. For BrO, the spectral range chosen

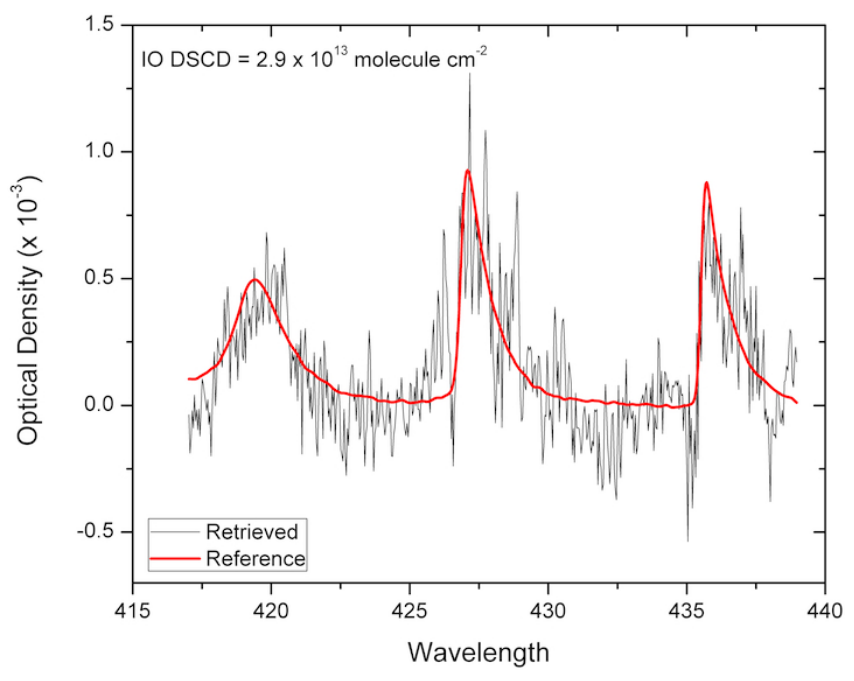

Fig. 2. An example of a DOAS fit for IO during the cruise. This particular fit is from 17 April 2010 at 15:00 LT (local time).

was $346-359 \mathrm{~nm}$, and the resulting $2 \sigma$ detection limit ranged from $6 \times 10^{13}$ to $12 \times 10^{13}$ molecules $\mathrm{cm}^{-2}$. The molecule was not observed over the detection limit throughout the campaign. A cloud index was used ( 0 - clear sky, 1 - cloudy sky) for estimating sky conditions. The filter was calculated using a ratio of radiation fluxes from the edges of the spectral window $(420 \mathrm{~nm}$ and $459 \mathrm{~nm})$ and elevation angles measured using the DOAS instrument in order to distinguish the predominant scattering conditions. This ratio was calculated between the zenith and $1^{\circ}$-elevation angles, with a low ratio indicating a cloudy environment. This ratio is used in conjunction with radiometer data, which were collected on board the cruise, and the DOAS retrieved $\mathrm{O}_{4}$ DSCDs. A threshold of 1.1 was calculated, above which the conditions were cloud free (cloud index of 0 ). It is difficult to compute the uncertainties on the cloud index; in fact, the filter is a stringent cutoff. This would mean that we are on the safe side, with a risk of disregarding some valid data near the threshold, but it ensures that only data from clear sky conditions was used for further analysis. A similar filter has been used previously by other groups for similar studies (Sinreich et al., 2010).

Surface IO mixing ratios were retrieved from the MAXDOAS DSCDs using the $\mathrm{O}_{4}$ slant columns measured during the study by the "O $\mathrm{O}_{4}$ method", similar to other groups (e.g., Wagner et al., 2004; Sinreich et al., 2010) and validated by the NIMO fully spherical Monte Carlo radiative transfer model (Hay et al., 2012) where possible, which is described in detail in the SI. Only the $1^{\circ}$ elevation angle data were used for retrieval using the $\mathrm{O}_{4}$ method, while all the elevation angles were used for retrieving IO mixing ratios using the radiative transfer model (RTM). However, the limited information content of the measurements renders the mathematical inversion to be dominated by the a priori information given in the RTM calculations. For the $\mathrm{O}_{4}$ method, the $\mathrm{O}_{4}$ 
DSCDs were divided by the modeled mean extinction coefficient of $\mathrm{O}_{4}$ from the surface to $200 \mathrm{~m}$ a.s.l. to obtain the path lengths. This layer height was based on the average last scatter altitude calculated with NIMO using the different aerosol profiles determined by forward modeling. A wavelength correction, calculated with the radiative transfer model, was applied to the path length since the $\mathrm{O}_{4}$ spectral analysis was performed on an absorption band at $360 \mathrm{~nm}$ whereas the IO analysis was centered on $427 \mathrm{~nm}$. IO mixing ratios were then obtained by dividing the IO DSCDs by these corrected path lengths.

$\mathrm{CH}_{3} \mathrm{I}$ and a suite of other halocarbons were measured continuously in air and surface seawater using GC-MS, equipped with a Weiss-type equilibrator (Hu et al., 2010; Yvon-Lewis et al., 2004). Air was continuously pumped $\left(\sim 6 \mathrm{~L} \mathrm{~min}^{-1}\right)$ through $0.63 \mathrm{~cm}$ ID SynFlex tubing (Motion Industries, Dallas, TX), which was mounted on the mast at the bow of the ship. Seawater from the ship flowed through a Weiss equilibrator (Butler et al., 1988; Johnson, 1999). Samples were periodically drawn from the equilibrated headspace of the Weiss equilibrator and from the air pumped from the bow. Air and equilibrator headspace samples were collected alternately every $\sim 56$, or 112 min depending on whether or not the calibration gas standard was in sequence. Each sample was drawn through a Nafion dryer, trapped on one cryotrap and pre-concentrated on a second trap, then injected into a narrow bore DB-VRX (I.D. $0.18 \mathrm{~mm}$; Length $40 \mathrm{~m}$; Film $1.0 \mu \mathrm{m})$ column and analyzed by GC-MS. The instrument was calibrated using two whole-air standards, which were calibrated against a whole air standard from NOAA/ESRL Global Monitoring Division using NOAA-03 scale. The precision for the $\mathrm{CH}_{3} \mathrm{I}$ measurements was approximately $8 \%$.

The net sea-to-air flux, $F\left(\mathrm{nmol} \mathrm{m}^{-2} \mathrm{~d}^{-1}\right)$ was determined from the following equation:

$F=\frac{k_{w}}{H}\left(p_{w}-p_{a}\right)$

where, $k_{w}$ is the gas transfer velocity $\left(\mathrm{m} \mathrm{d}^{-1}\right.$ ) (Sweeney et al., 2007); $H$ is the solubility of $\mathrm{CH}_{3} \mathrm{I}\left(\mathrm{m}^{3} \mathrm{~atm} \mathrm{~mol}{ }^{-1}\right.$ ) (Elliott and Rowland, 1993; Mabey and Mill, 1978); $p$ is the measured partial pressure in the atmosphere $(a)$ or in equilibrium with the surface ocean $(w)$.

In addition to the in situ data, Chl $a$ and CDOM index products were obtained using Level-3 daily global fields at $9 \mathrm{~km}$ horizontal resolution from the Aqua MODIS satellite instrument (NASA-GSFC, 2011). Missing pixels were substituted with the average from the eight surrounding pixels on the same day, the average from the last three days, or the average from the last eight days in the worst-case scenario. Composite fields for the month of April were used for filling in missing data. Average and weighted exposure to $\mathrm{Chl} a$ and $\mathrm{CDOM}$ of the air masses arriving at the ship were obtained by integrating the satellite data fields along five day back trajectories calculated with the HYSPLIT dispersion model (Draxler and Rolph, 2003). In order to restrict the influence

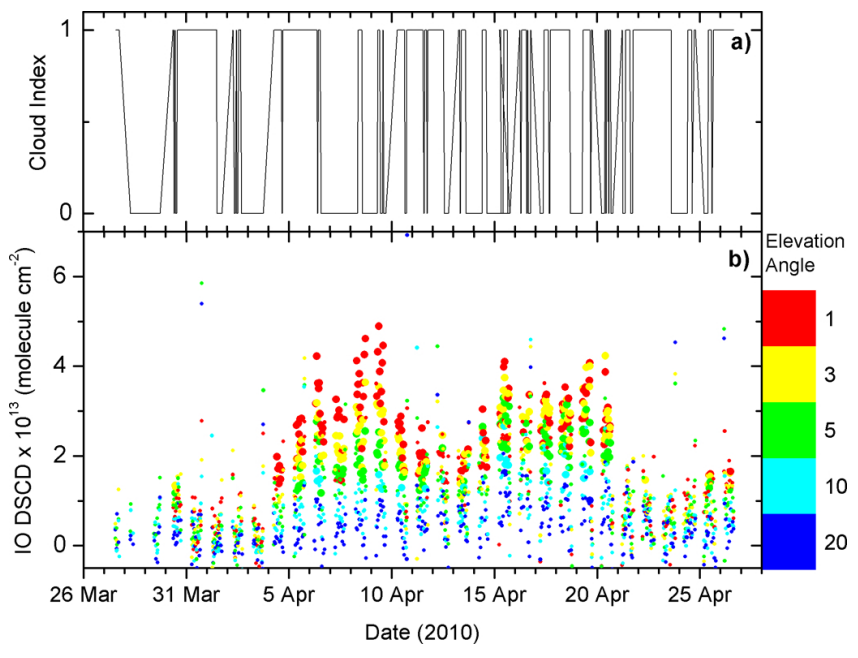

Fig. 3. MAX-DOAS observations of IO DSCDs made during the HaloCAST-P cruise. Panel (a) shows the cloud index during the cruise ( 1 - cloudy, 0 - not cloudy). Panel (b) illustrates the IO DSCDs with the statistically significant values as larger circles. The elevation angles for the observations are indicated in the legend.

of the air masses to the MBL, Chl $a$ and CDOM values are considered to contribute only where the trajectory pressure is greater than $850 \mathrm{hPa}$ and when the trajectory passes over the sea, using a procedure similar to Arnold et al. (2010).

In situ measurements of $\mathrm{O}_{3}$ were not made during the cruise, and hence, in order to study possible dependencies on $\mathrm{O}_{3}$ and to estimate total reactive iodine in the MBL, monthly averaged output along the trajectory of the cruise from the global chemistry climate model, CAM-Chem (Lamarque et al., 2012), was used. The model has been validated in the past (Saiz-Lopez et al., 2012a) and was revalidated recently for $\mathrm{O}_{3}$ mixing ratios at the surface at latitude $1^{\circ} \mathrm{S}$, where year-long ground based measurements of $\mathrm{O}_{3}$ were made at the Galapagos Islands and agree well with the model simulation for April 2011 (note that the meteorological conditions in the Eastern Pacific and model estimates from CAM-Chem were similar in April 2010 and 2011).

\section{Results and discussion}

IO was observed above the detection limit on 19 out of 31 days during the campaign. Most of the positive detections were in the open ocean environment. Of the other 12 days, bad weather or persistent cloud coverage resulted in no reliable observations on seven days. On the rest of the remaining five days, IO was under the detection limit of the instrument. The calculated cloud index (Fig. 3a) shows that, although clouds were present for some part of the day during most of the campaign, enough clear sky conditions were available for reliable observations. The cloud index was used to filter the data for studying the correlation of IO with various 


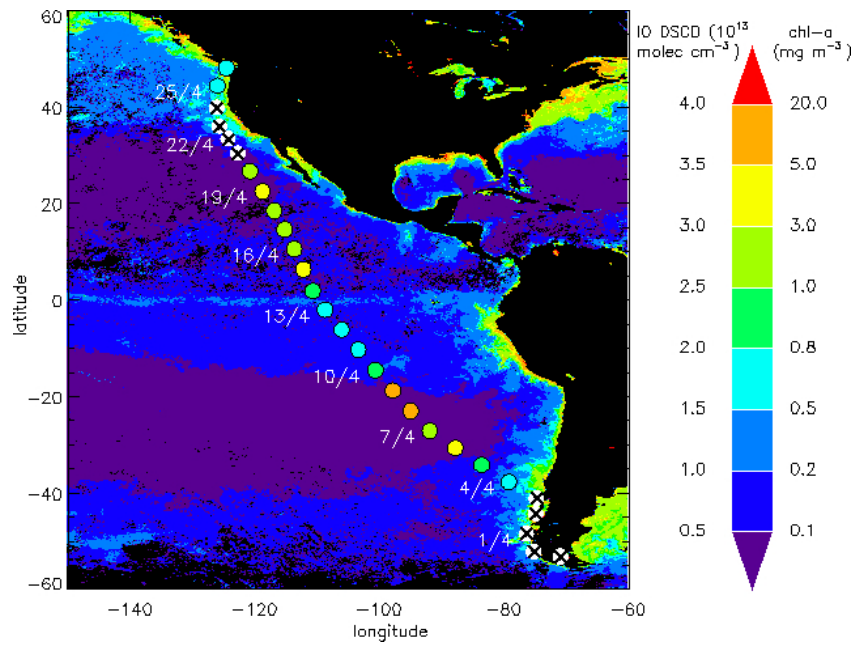

Fig. 4. The daily average IO DSCDs over the detection limit in the $1^{\circ}$ viewing elevation angle after the data was filtered for clouds along with satellite estimated Chl $a$ distribution for April 2010 (NASA-GSFC, 2011). The empty white circles with crosses show days where measurements were not possible.

physical and biotic parameters. The IO DSCD time series for the whole campaign is presented in Fig. 3b. The highest DSCD $\left(4.9 \times 10^{13}\right.$ molecules $\left.\mathrm{cm}^{-2}\right)$ was observed on April $9\left(\mathrm{SZA}=51^{\circ}\right)$. Figure 4 shows the distribution of daily average IO DSCD along the ship track after using the cloud index and detection limits as filters. The maxima are observed south of the equator, between $20^{\circ} \mathrm{S}$ and $40^{\circ} \mathrm{S}$. A reduction in the retrieved DSCDs was observed closer to the equator, while a second maximum was measured further north, between $5^{\circ} \mathrm{N}$ and $20^{\circ} \mathrm{N}$ (Fig. 4). Reactive iodine $\left(\mathrm{IO}_{\mathrm{x}}=\mathrm{I}+\mathrm{IO}\right)$ was then calculated using the Tropospheric HAlogen chemistry MOdel (THAMO) (Saiz-Lopez et al., 2008), which has been used for previous studies in polar, mid-latitudinal and tropical environments (Mahajan et al., 2009, 2010a, b; SaizLopez et al., 2008). The model is initialized using observed meteorological conditions where available and output from CAM-CHEM for $\mathrm{O}_{3}$ and $\mathrm{NO}_{\mathrm{x}}$ (Lamarque et al., 2012; SaizLopez et al., 2012a), which were not measured during the campaign. The source of iodine in the open ocean environment is considered to be mainly photochemically produced $\mathrm{I}_{2}$ from the ocean surface, in accord with past reports (Jones et al., 2010; Mahajan et al., 2010a). The flux is then tuned to reproduce the average daytime surface mixing ratios along the cruise track and then the total $\mathrm{IO}_{\mathrm{x}}$ is calculated for further correlations. IO dominates $\mathrm{IO}_{\mathrm{x}}$ during most of the cruise due to high $\mathrm{O}_{3}$ mixing ratios. $\mathrm{IO}: \mathrm{I} \sim 0.12 \times\left[\mathrm{O}_{3}\right]-$ although this shows some diurnal variation, which is considered in the model. This means that for $1 \mathrm{pptv}$ of IO, a two-fold change in $\mathrm{O}_{3}$ from 20 to $40 \mathrm{ppb}$ would cause $\mathrm{IO}_{\mathrm{x}}$ to decrease by $0.24 \mathrm{pptv}-$ which is well within the variation observed in the $\mathrm{IO}_{\mathrm{x}}$. However, in regions with low $\mathrm{O}_{3}$, the $\mathrm{IO}$ : I ratio shifted towards I. The proportionality constant $0.12 \mathrm{ppb}^{-1}$ is calcu-

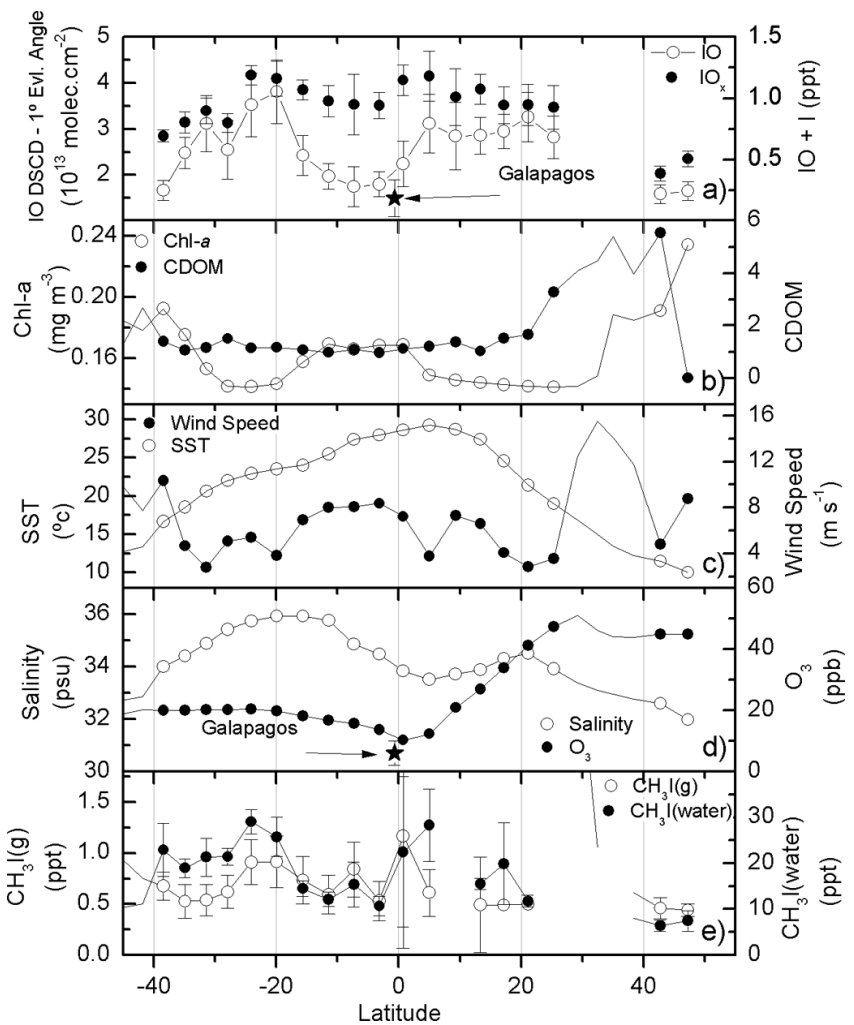

Fig. 5. Latitudinal distribution of IO DSCDs, calculated total reactive iodine $\mathrm{IO}_{\mathrm{x}}(\mathrm{I}+\mathrm{IO})$ and other parameters measured during the cruise. Circles are shown only when IO was observed above the detection limit. Note that IO DSCD and $\left[\mathrm{O}_{3}\right]$ observations made on the same day of the year (in 2011) during an ongoing ground-based field study on the Galapagos Islands, indicated as stars, are in accord with observations at the same latitude during the cruise. Circles are shown only when IO was observed above the detection limit.

lated for a range of $\mathrm{O}_{3}$ from 5-40 ppb for daytime conditions assuming clear sky conditions using THAMO, as described above. Total $\mathrm{IO}_{\mathrm{x}}$ was found to be insensitive to $\mathrm{NO}_{\mathrm{x}}$ within the range observed in the open ocean environment due to low levels of $\mathrm{I}$ in regions with relatively larger $\mathrm{NO}_{\mathrm{x}}$ concentrations. Changing the $\mathrm{NO}_{2}$ mixing ratios in the model from 5 to 20 pptv causes a $7 \%$ change in modeled $\mathrm{IO}_{\mathrm{x}}$. Further details about the model, including the list of reactions can be found elsewhere (Mahajan et al., 2010a; Saiz-Lopez et al., 2008). The resulting $\mathrm{IO}_{\mathrm{x}}$ was then used to study the dependence of iodine compounds on other parameters measured during the cruise. The latitudinal distribution of IO DSCDs, IO mixing ratios at the surface estimated using the $\mathrm{O}_{4}$ DSCDs, and $\mathrm{IO}_{\mathrm{x}}$ mixing ratios calculated using THAMO, are shown in Fig. S1.

Figure 5 shows the latitudinal variation in parameters measured during the HaloCAST-P cruise, along with daytime average IO DSCDs and $\mathrm{IO}_{\mathrm{x}}$ mixing ratios at the surface (panel a). The IO DSCDs and $\mathrm{IO}_{\mathrm{x}}$ mixing ratios broadly follow each other. $\mathrm{IO}_{\mathrm{x}}$ shows a double peak with a maximum 


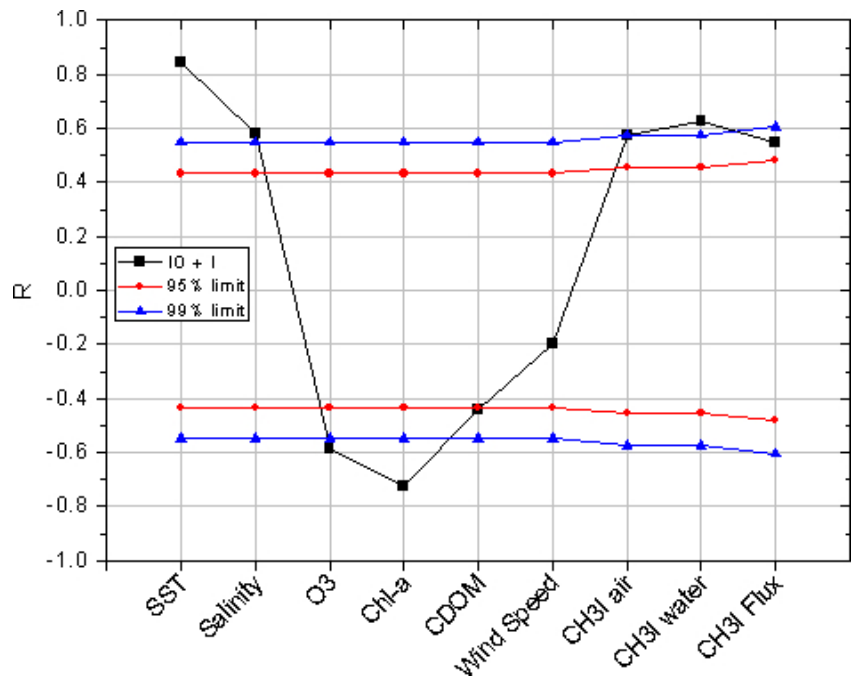

Fig. 6. Pearson correlation coefficients for $\mathrm{IO}_{\mathrm{x}}$ with individual parameters, along with $95 \%$ and $99 \%$ confidence limits are shown. $\mathrm{IO}_{\mathrm{x}}$ is positively correlated with SST and salinity, $\mathrm{CH}_{3} \mathrm{I}$ in air and water but negatively correlated with $\mathrm{O}_{3}$ and $\mathrm{Chl} a$ within the $99 \%$ confidence limits. It is also positively correlated to $\mathrm{CH}_{3} \mathrm{I}$ flux and negatively correlated to CDOM within $95 \%$ confidence, while no significant correlation is seen with wind speed.

of $\sim 1.2 \mathrm{pptv}$ close to $20^{\circ} \mathrm{S}$ and $10^{\circ} \mathrm{N}$, with values between $20^{\circ} \mathrm{S}$ and $20^{\circ} \mathrm{N}$ consistently close to $1 \mathrm{pptv}$. The estimated amplitude of the change in $\mathrm{IO}_{\mathrm{x}}$ around the equator is different to that of the IO DSCDs but similar to the IO mixing ratios suggesting a change in aerosol loading. Lower mixing ratios were observed in the mid-latitudinal open ocean, with the lowest values above detection limit close to the North American coast. Other ancillary data, including $\mathrm{Chl} a$, CDOM, SST, wind speed, salinity and $\mathrm{O}_{3}$ mixing ratios are shown in Fig. 5b, $c$ and d. These variables illustrate the different environments encountered during the cruise: for example, the range of observed SST is almost $\sim 19^{\circ} \mathrm{C}$ with low temperatures close to the coast in the mid-latitudes and higher temperatures in the open ocean close to the equator, while salinity showed a peak of $\sim 36 \mathrm{psu}$ at about $20^{\circ} \mathrm{S}$ with lower values in the mid-latitudes. By contrast, both Chl $a$ and CDOM were higher in the mid-latitudes with the highest observed values close to the coast (Figs. 4 and $5 \mathrm{~b}$ ). Modeled $\mathrm{O}_{3}$ mixing ratios were lower south of the equator with increasingly higher values observed north of the equator. The variation in $\mathrm{CH}_{3} \mathrm{I}$ mixing ratios, both in air and surface seawater, is shown in Fig. 5e. They both followed a similar trend, with higher values observed close to $20^{\circ} \mathrm{S}$ and just north of the equator.

The error-weighted correlation coefficients between daily averaged $\mathrm{IO}_{\mathrm{x}}$ and the other parameters listed above were calculated in order to understand which parameters control the fluxes of iodine in the open ocean environment (Fig. 6). Amongst the physical parameters, $\mathrm{IO}_{\mathrm{x}}$ showed a strong pos- itive correlation within a confidence limit of $99 \%$, with SST and salinity, while negative correlations with $\mathrm{Chl} a$ and $\mathrm{O}_{3}$ were observed. The negative correlation between $\mathrm{IO}_{\mathrm{x}}$ and CDOM was significant within the $95 \%$ confidence limit. No significant correlation was observed with wind speed. Strong correspondence was also observed with $\mathrm{CH}_{3} \mathrm{I}$ mixing ratios in air and water ( $>99 \%$ confidence), while the correlation with $\mathrm{CH}_{3} \mathrm{I}$ flux from the ocean was within $95 \%$ confidence (Fig. 6). This indicates that the sources of $\mathrm{CH}_{3} \mathrm{I}$ and the shorter-lived precursors of $\mathrm{IO}_{\mathrm{x}}$ (most likely $\mathrm{I}_{2}$, Mahajan et al., 2010a or HOI) are related or depend upon similar variables. $\mathrm{CH}_{3} \mathrm{I}$ itself cannot account for the $\mathrm{IO}_{\mathrm{x}}$ observed during the study, contributing only $\sim 20 \%$ of the necessary reactive iodine flux at its maximum concentration close to the equator due to its long photolysis lifetime ( $\sim 5$ days in the tropics) in the MBL.

The significant negative correlation of $\mathrm{IO}_{\mathrm{x}}$ with $\mathrm{Chl} a$ suggests that the main source for the boundary layer iodine is unlikely to be emission of organic and inorganic iodine compounds by biotic sources such as phytoplankton and macro algae, which have been shown to be the dominant source in coastal environments (Carpenter et al., 1999; Saiz-Lopez and Plane, 2004). Moreover, $\mathrm{CH}_{3} \mathrm{I}$ mixing ratios in air did not show any significant positive correlation with 1-5 day air mass exposure to $\mathrm{Chl} a$. Such a correlation was recently reported between both $\mathrm{CH}_{3} \mathrm{I}$ and aerosol phase iodine (observations of reactive inorganic iodine were not made) and air-mass exposure to $\mathrm{Chl} a$ on a cruise from South Africa to South America (Arnold et al., 2010; Lai et al., 2011). It should be noted that the $\mathrm{Chl} a$ levels during that cruise ranged from 0.03 to $4.63 \mathrm{mg} \mathrm{m}^{-3}$ with $\mathrm{CH}_{3} \mathrm{I}$ mixing ratios in air peaking at $3 \mathrm{pptv}$, while during our study Chl $a$ was always lower than $0.25 \mathrm{mg} \mathrm{m}^{-3}$ and $\mathrm{CH}_{3} \mathrm{I}$ in air peaked at 1.1 pptv. Phytoplankton species in the Southern Atlantic and Eastern Pacific are known to be different with iodine compound emitting diatoms (Hill and Manley, 2009) more abundant in the Southern Atlantic (Bracher et al., 2009); hence the possibility of a different source regime cannot be ruled out. Similar contrasting reports have also been observed in laboratory studies; Smythe-Wright et al. $(2006,2010)$ found large emission of $\mathrm{CH}_{3} \mathrm{I}$ by phytoplankton, while Brownell et al. (2010) reported much lower emission rates from similar species. A negative correlation between $\mathrm{IO}_{\mathrm{x}}$ and CDOM suggests that the presence of DOM is not the rate-limiting factor for emission of iodine compounds. Indeed the emissions of iodocarbons have been shown to be independent of the amount of CDOM in surface water by Martino et al. (2009).

A negative correlation of $\mathrm{IO}_{\mathrm{x}}$ with $\mathrm{O}_{3}$ is surprising considering that most laboratory studies have shown increased emission of iodine containing compounds, inorganic and organic, over seawater exposed to $\mathrm{O}_{3}$ (Garland and Curtis, 1981; Martino et al., 2009). Several mechanisms for the emission of iodine compounds have been suggested, including the oxidation of $\mathrm{I}^{-}$to $\mathrm{HOI}$ and either direct emission of $\mathrm{HOI}$, further reaction with $\mathrm{I}^{-}$to form $\mathrm{I}_{2}$ or reaction of 
HOI with CDOM to cause emission of iodocarbons (Garland and Curtis, 1981; Jammoul et al., 2009; Martino et al., 2009). One possibility is that the threshold of $\mathrm{O}_{3}$ required for emission of iodine compounds is lower than predicted during the cruise. $\mathrm{O}_{3}$ is predicted to range between 10 and $50 \mathrm{ppbv}$ over the cruise track and even the presence of $10 \mathrm{ppbv}$ could be enough for the release mechanism to function. However, this would not explain the significant negative correlation between $\mathrm{O}_{3}$ and $\mathrm{IO}_{\mathrm{x}}$. It is also unlikely that the anti-correlation with $\mathrm{O}_{3}$ is a result of $\mathrm{O}_{3}$ depletion due to iodine chemistry because of the low $\mathrm{IO}_{\mathrm{x}}$ mixing ratios $\left(1.2 \mathrm{pptv}\right.$ of $\mathrm{IO}_{\mathrm{x}}$ would cause $\sim 7 \% \mathrm{O}_{3}$ depletion in one day). It should be noted that in the absence of continuous $\mathrm{O}_{3}$ measurements on the cruise, the indication of an anti-correlation between $\mathrm{IO}_{\mathrm{x}}$ and $\mathrm{O}_{3}$ (determined from CAM-Chem) should be regarded as tentative.

$\mathrm{IO}_{\mathrm{x}}$ shows a strong correlation with the physical oceanic parameters of SST and salinity. To our knowledge, this is the first time such correlations have been observed in the open ocean. No correlation was observed with wind speed suggesting that physical mixing in the upper water column is not a rate-limiting step for the emission mechanism. Larger $\mathrm{IO}_{\mathrm{x}}$ with higher SST could result from increased phase transfer of iodine source gases such as $\mathrm{I}_{2}$, HOI, etc., which have low solubility in water, or an increase in the rate of production of these compounds at higher temperatures. Similarly, an increase in salinity would account for greater iodine availability (as iodate or iodide) in seawater, which could enhance their emission rates. However, $\mathrm{CH}_{3} \mathrm{I}$ did not show significant correlation with SST or salinity but rather a positive correlation with CDOM ( $>95 \%$ confidence), suggesting different sources. Note that the linear correlations observed between $\mathrm{IO}_{\mathrm{x}}$ and SST and salinity do not display a strong slope (SST: $0.033 \pm 0.005 \mathrm{pptv}^{\circ} \mathrm{C}^{-1}$; salinity: $\left.0.12 \pm 0.04 \mathrm{pptv} \mathrm{psu}^{-1}\right)$. Considering the range of variability observed during this study, the observations suggest a very weak variation of emissions under a warming ocean scenario. However, the exact mechanism for emission of iodine compounds is still not known, neither is it clear which would be the dominant source (see Saiz-Lopez et al., 2012b and references therein), making extrapolation to other scenarios complex. The presence of strong correlations with several parameters, some of which do not co-vary with each other, indicates that such a mechanism would be a function of multiple variables, which should be considered in future laboratory studies.

The IO slant columns and the derived surface mixing ratios observed during this study are inconsistent with previous reports of measurements made using the SCIAMACHY instrument (Schönhardt et al., 2008). The observations by SCIAMACHY predicted a distribution tracking the biologically active regions off the coast of Peru, with the open ocean slant columns peaking at about $10^{\circ} \mathrm{N}$ over the region overlapping with the cruise track. Our observations indicate a peak in regions without high biological activity, with a maximum in IO at $20^{\circ} \mathrm{S}$, where the satellite predicts a minimum. However, this peak is not vastly different than around the equator suggesting a small variation contrary to the satellite estimates. The total IO mixing ratios, peaking at $0.9 \mathrm{pptv}$ are also lower than estimates from satellite, observations even after considering the uncertainty. If evenly distributed in the MBL the satellite estimated IO would amount to $\sim 3$ pptv about three fold higher than our observations. It should be noted that the signal-to-noise for the satellite observations is poor above the open ocean and hence the values estimated could be misleading. It is however possible that satellite observations might not be representative of the MBL iodine loading and could indicate a large free tropospheric IO column. However, such a free tropospheric column would not explain the large differences in its geographical distribution.

\section{Conclusions}

In summary, IO was observed in the Eastern Pacific open ocean environment, exhibiting strong positive correlations with SST and salinity. However, contrary to previous laboratory studies, a negative correlation was observed with $\mathrm{Chl} a$ and CDOM, suggesting that iodine production in the open ocean is not enhanced but might instead be inhibited by either of these. This study provides field evidence for a widespread non-biological mechanism for the emission of iodine precursors dependent on physical variables such as SST and salinity. The data indicates that emission of iodine compounds is not controlled by any single variable but is most probably dependent on multiple factors. Finally, these observations do not agree well with previous satellite measurements (Schönhardt et al., 2008), finding a different geographical distribution and lower IO mixing ratios in the MBL.

\section{Supplementary material related to this article is available online at: http://www.atmos-chem-phys.net/12/ 11609/2012/acp-12-11609-2012-supplement.pdf.}

Acknowledgements. The Spanish Research Council and the Regional Government of Castilla-La Mancha funded this work. S. Yvon-Lewis acknowledges funding from the National Science Foundation (NSF/OCE 0927874) supporting the shiptime and the halocarbon measurements. The authors thank the captain and crew of the UNOLS R/V Thomas Thompson for their support during the cruise and Denis Pöhler and the University of Heidelberg for supplying the gimbal system.

Edited by: R. McLaren

\section{References}

Allan, B. J., McFiggans, G. B., Plane, J. M. C. C., Coe, H., McFadyen, G. G., Carpenter, L. J., and O'Dowd, C. D.: Observations of iodine monoxide in the remote marine boundary 
layer, J. Geophys. Res.-Atmos., 105, 24191-24204, doi:01480227/00/1999JD901187, 2000.

Arnold, S. R., Spracklen, D. V., Gebhardt, A. S., Custer, B. T., Williams, B. J., Peeken, I., and Alvain, S.: Relationships between atmospheric organic compounds and air-mass exposure to marine biology, Environ. Chem., 7, 232-241, doi:10.1071/EN09144, 2010.

Bracher, A., Vountas, M., Dinter, T., Burrows, J. P., Röttgers, R., and Peeken, I.: Quantitative observation of cyanobacteria and diatoms from space using PhytoDOAS on SCIAMACHY data, Biogeosciences, 6, 751-764, doi:10.5194/bg-6-751-2009, 2009.

Brownell, D. K., Moore, R. M., and Cullen, J. J.: Production of methyl halides by Prochlorococcus and Synechococcus, Global Biogeochem. Cy., 24, 1-7, doi:10.1029/2009GB003671, 2010.

Burrows, J. P., Richter, A., Dehn, A., Deters, B., Himmelmann, S., Voigt, S., and Orphal, J.: Atmospheric remote-sensing reference data from GOME-2. Temperature-dependant absorption cross sections of $\mathrm{O}_{3}$ in the 231-794 nm range, J. Quant. Spectrosc. Ra., 61, 509-517, 1999.

Butler, J. H., Elkins, J. W., Brunson, C. M., Egan, K. B., Thompson, T. M., Conway, T. J., and Hall, B. D.: Trace gases in and over the west Pacific and the east Indian Oceans during the El Niño Southern Oscillation event of 1987, in: A Report of GMCC Data Collected on the Second Soviet-American Gas and Aerosol Experiment (SAGA II), NOAA Data Rep. ERL ARL-16, National Oceanic and Atmosphere Administration, Silver Spring, Md, 104 pp., 1988.

Carpenter, L. J., Sturges, W. T., Penkett, S. A., Liss, P. S., Alicke, B., Hebestreit, K. and Platt, U.: Short-lived alkyl iodides and bromides at Mace Head, Ireland?: Links to biogenic sources and halogen oxide production, J. Geophys. Res., 104, 1679-1689, 1999.

Chance, K. V. and Spurr, R. J.: Ring effect studies: Rayleigh scattering, including molecular parameters for rotational Raman scattering, and the Fraunhofer spectrum, Appl. Optics, 36, 52245230, 1997.

Draxler, R. and Rolph, G.: HYSPLIT (HYbrid Single Particle Lagrangian Integrated Trajectory), Model access via NOAA ARL Ready, http://www.arl.noaa.gov/ready/hysplit4.html, 2003.

Elliott, S. and Rowland, F. S.: Nucleophilic substitution rates and solubilities for methyl halides in seawater, Geophys. Res. Lett., 20, 1043-1046, 1993.

Fayt, C. and Van Roozendael, M.: QDOAS 1.00. Software User Manual, http://uv-vis.aeronomie.be/software/QDOAS/, 2011.

Garland, J. A. and Curtis, H.: Emission of Iodine From the Sea Surface in the Presence of Ozone, J. Geophys. Res., 86, 3183-3186, doi:10.1029/JC086iC04p03183, 1981.

Gómez Martín, J. C., Spietz, P., and Burrows, J. P.: Spectroscopic studies of the I-2/O-3 photochemistry - Part 1: Determination of the absolute absorption cross sections of iodine oxides of atmospheric relevance, J. Photoch. Photobio. A, 176, 15-38, 2005.

Hay, T. D., Bodeker, G. E., Kreher, K., Schofield, R., Liley, B., Scherer, M., and McDonald, A. J.: The NIMO Monte Carlo radiative transfer model for box-air-mass-factor and radiance calculations, J. Quant. Spectrosc. Ra., 113, 721-738, doi:10.1016/j.jqsrt.2012.02.005, 2012.

Hermans, C.: Measurement of absorption cross sections and spectroscopic molecular parameters: $\mathrm{O}_{2}$ and its collisonal induced absorption, http://spectrolab.aeronomie.be/o2.htm, 2002.
Hill, V. L. and Manley, S. L.: Release of reactive bromine and iodine from diatoms and its possible role in halogen transfer in polar and tropical oceans, Limnol. Oceanogr., 54, 812-822, 2009.

Hu, L., Yvon-Lewis, S. A., Liu, Y., Salisbury, J. E., and O'Hern, J. E.: Coastal emissions of methyl bromide and methyl chloride along the eastern Gulf of Mexico and the east coast of the United States, Global Biogeochem. Cy., 24, GB1007, doi:10.1029/2009GB003514, 2010.

Hönninger, G., von Friedeburg, C., and Platt, U.: Multi axis differential optical absorption spectroscopy (MAX-DOAS), Atmos. Chem. Phys., 4, 231-254, doi:10.5194/acp-4-231-2004, 2004.

Jammoul, A., Dumas, S., D'Anna, B., and George, C.: Photoinduced oxidation of sea salt halides by aromatic ketones: a source of halogenated radicals, Atmos. Chem. Phys., 9, 4229-4237, doi:10.5194/acp-9-4229-2009, 2009.

Johnson, J. E.: Evaluation of a seawater equilibrator for shipboard analysis of dissolved oceanic trace gases, Anal. Chim. Acta, 395, 119-132, doi:10.1016/S0003-2670(99)00361-X, 1999.

Jones, C. E., Hornsby, K. E., Sommariva, R., Dunk, R. M., von Glasow, R., McFiggans, G. B., and Carpenter, L. J.: Quantifying the contribution of marine organic gases to atmospheric iodine, Geophys. Res. Lett., 37, L18804, doi:10.1029/2010GL043990, 2010.

Lai, S. C., Williams, J., Arnold, S. R., Atlas, E. L., Gebhardt, S., and Hoffmann, T.: Iodine containing species in the remote marine boundary layer: A link to oceanic phytoplankton, Geophys. Res. Lett., 38, 1-5, doi:10.1029/2011GL049035, 2011.

Lamarque, J.-F., Emmons, L. K., Hess, P. G., Kinnison, D. E., Tilmes, S., Vitt, F., Heald, C. L., Holland, E. A., Lauritzen, P. H., Neu, J., Orlando, J. J., Rasch, P. J., and Tyndall, G. K.: CAM-chem: description and evaluation of interactive atmospheric chemistry in the Community Earth System Model, Geosci. Model Dev., 5, 369-411, doi:10.5194/gmd-5-369-2012, 2012.

Mabey, W. and Mill, T.: Critical Review of Hydrolysis of Organic Compounds in Water Under Environmental Conditions, J. Phys. Chem. Ref. Data, 7, 383, doi:10.1063/1.555572, 1978.

Mahajan, A. S., Oetjen, H., Saiz-Lopez, A., Lee, J. D., McFiggans, G. B., and Plane, J. M. C.: Reactive iodine species in a semi-polluted environment, Geophys. Res. Lett., 36, L16803, doi:10.1029/2009GL038018, 2009.

Mahajan, A. S., Plane, J. M. C., Oetjen, H., Mendes, L., Saunders, R. W., Saiz-Lopez, A., Jones, C. E., Carpenter, L. J., and McFiggans, G. B.: Measurement and modelling of tropospheric reactive halogen species over the tropical Atlantic Ocean, Atmos. Chem. Phys., 10, 4611-4624, doi:10.5194/acp-10-4611-2010, 2010a.

Mahajan, A. S., Shaw, M., Oetjen, H., Hornsby, K. E., Carpenter, L. J., Kaleschke, L., Tian-Kunze, X., Lee, J. D., Moller, S. J., Edwards, P., Commane, R., Ingham, T., Heard, D. E., and Plane, J. M. C.: Evidence of reactive iodine chemistry in the Arctic boundary layer, J. Geophys. Res., 115, D20303, doi:10.1029/2009JD013665, 2010 b.

Martino, M., Mills, G. P., Woetjen, J. and Liss, P. S.: A new source of volatile organoiodine compounds in surface seawater, Geophys. Res. Lett., 36, L01609, doi:10.1029/2008GL036334, 2009.

Moore, R. M. and Zafiriou, O. C.: Photochemical production of methyl-iodine in seawater, J. Geophys. Res.-Atmos., 99, 16415$16420,1994$. 
NASA-GSFC: Ocean Color Web, available at: http://oceancolor. gsfc.nasa.gov/, 2011.

Oetjen, H.: Measurements of halogen oxides by scattered sunlight differential optical absorption spectroscopy, University of Bremen, 2009.

Platt, U. and Stutz, J.: Differential optical absorption spectroscopy: Principles and applications, 1st Edn., Springer, 2008.

Read, K. A., Mahajan, A. S., Carpenter, L. J., Evans, M. J., Faria, B. V. E., Heard, D. E., Hopkins, J. R., Lee, J. D., Moller, S. J., Lewis, A. C., Mendes, L., McQuaid, J. B., Oetjen, H., Saiz-Lopez, A., Pilling, M. J., and Plane, J. M. C.: Extensive halogen-mediated ozone destruction over the tropical Atlantic Ocean, Nature, 453, 1232-1235, 2008.

Reeser, D. I., George, C., and Donaldson, D. J.: Photooxidation of halides by chlorophyll at the air-salt water interface., J. Phys. Chem. A, 113, 8591-8595, doi:10.1021/jp903657j, 2009.

Rothman, L. S., Barbe, A., Benner, D. C., Brown, L. R., CamyPeyret, C., Carleer, M. R., Chance, K. V., Clerbaux, C., Dana, V., Devi, V. M., Fayt, A., Flaud, J. M., Gamache, R. R., Goldman, A., Jacquemart, D., Jucks, K. W., Lafferty, W. J., Mandin, J. Y., Massie, S. T., Nemtchinov, V., Newnham, D. A., Perrin, A., Rinsland, C. P., Schroeder, J., Smith, K. M., Smith, M. A. H., Tang, K., Toth, R. A., Vander Auwera, J., Varanasi, P., and Yoshino, K.: The HITRAN molecular spectroscopic database: edition of 2000 including updates through 2001, J. Quant. Spectrosc. Ra., 82, 5-44, 2003.

Saiz-Lopez, A. and Plane, J. M. C.: Novel iodine chemistry in the marine boundary layer, Geophys. Res. Lett., 31, L04112, doi:10.1029/2003GL019215, 2004.

Saiz-Lopez, A., Plane, J. M. C., Mahajan, A. S., Anderson, P. S., Bauguitte, S. J.-B., Jones, A. E., Roscoe, H. K., Salmon, R. A., Bloss, W. J., Lee, J. D., and Heard, D. E.: On the vertical distribution of boundary layer halogens over coastal Antarctica: implications for $\mathrm{O}_{3}, \mathrm{HO}_{\mathrm{x}}, \mathrm{NO}_{\mathrm{x}}$ and the $\mathrm{Hg}$ lifetime, Atmos. Chem. Phys., 8, 887-900, doi:10.5194/acp-8-887-2008, 2008.

Saiz-Lopez, A., Lamarque, J.-F., Kinnison, D. E., Tilmes, S., Ordóñez, C., Orlando, J. J., Conley, A. J., Plane, J. M. C., Mahajan, A. S., Sousa Santos, G., Atlas, E. L., Blake, D. R., Sander, S. P., Schauffler, S., Thompson, A. M., and Brasseur, G.: Estimating the climate significance of halogen-driven ozone loss in the tropical marine troposphere, Atmos. Chem. Phys., 12, 3939-3949, doi:10.5194/acp-12-3939-2012, 2012a.

Saiz-Lopez, A., Plane, J. M. C., Baker, A. R., Carpenter, L. J., von Glasow, R., Gómez Martín, J. C., McFiggans, G. B., and Saunders, R. W.: Atmospheric Chemistry of Iodine, Chem. Rev., 112, 1773-1804, doi:10.1021/cr200029u, 2012b.
Schönhardt, A., Richter, A., Wittrock, F., Kirk, H., Oetjen, H., Roscoe, H. K., and Burrows, J. P.: Observations of iodine monoxide columns from satellite, Atmos. Chem. Phys., 8, 637-653, doi:10.5194/acp-8-637-2008, 2008.

Sinreich, R., Coburn, S., Dix, B., and Volkamer, R.: Ship-based detection of glyoxal over the remote tropical Pacific Ocean, Atmos. Chem. Phys., 10, 11359-11371, doi:10.5194/acp-1011359-2010, 2010.

Smythe-Wright, D., Boswell, S. M., Breithaupt, P., Davidson, R. D., Dimmer, C. H., and Diaz, L. B. E.: Methyl iodide production in the ocean: Implications for climate change, Global Biogeochem. Cy., 20, GB3003, doi:10.1029/2005GB002642, 2006.

Smythe-Wright, D., Peckett, C., Boswell, S., and Harrison, R.: Controls on the production of organohalogens by phytoplankton?: Effect of nitrate concentration and grazing, J. Geophys. Res., 115, 1-11, G03020, doi:10.1029/2009JG001036, 2010.

Sweeney, C., Gloor, E., Jacobson, A. R., Key, R. M., McKinley, G., Sarmiento, J. L., and Wanninkhof, R.: Constraining global air-sea gas exchange for $\mathrm{CO}_{2}$ with recent bomb ${ }^{14} \mathrm{C}$ measurements, Global Biogeochem. Cy., 21, 1-10, doi:10.1029/2006GB002784, 2007.

Vandaele, A. C., Hermans, C., Simon, P., Carleer, M. R., Colins, R., Fally, F., Merienne, M. F., Jenouvrier, A., and Coquart, B.: Measurements of $\mathrm{NO}_{2}$ absorption cross-sections at $42000 \mathrm{~cm}^{-1}$ to $10000 \mathrm{~cm}^{-1}(238-1000 \mathrm{~nm})$ at $220 \mathrm{~K}$ and $298 \mathrm{~K}$, J. Quant. Spectrosc. Ra., 59, 171-184, 1997.

Wagner, T., Dix, B., Friedeburg, C. v., Frieß, U., Sanghavi, S., Sinreich, R., and Platt, U.: MAX-DOAS $\mathrm{O}_{4}$ measurements: A new technique to derive information on atmospheric aerosols - Principles and information content, J. Geophys. Res., 109, D22205, doi:10.1029/2004JD004904, 2004.

Williams, J., Gros, V., Atlas, E. L., Maciejczyk, K., Batsaikhan, A., Schöler, H. F., Forster, C., Quack, B., Yassaa, N., Sander, R., and Dingenen, R. V.: Possible evidence for a connection between methyl iodide emissions and Saharan dust, J. Geophys. Res., 112, D07302, doi:10.1029/2005JD006702, 2007.

Yvon-Lewis, S. A., King, D. B., Tokarczyk, R., Goodwin, K. D., Saltzman, E. S., and Butler, J. H.: Methyl bromide and methyl chloride in the Southern Ocean, J. Geophys. Res.-Atmos., 109, C02008, doi:10.1029/2003JC001809, 2004. 